\title{
Chromatin Structure through the Cell Cycle
}

\author{
STUDIES WITH REGENERATING RAT LIVER
}

\author{
By ARNOLD CAPLAN* \\ Faculté de Médecine de Strasbourg, Institute de Chimie Biologique, 11 Rue Humann, 67085 Strasbourg, France \\ and MARGERY G. ORD and LLOYD A. STOCKEN \\ Department of Biochemistry, University of Oxford, South Parks Road, Oxford OX13QU, U.K.
}

(Received 18 January 1978)

\begin{abstract}
Liver nuclei were prepared through the first cell cycle in partially hepatectomized young rats showing $30 \%$ parenchymal cell synchrony. To determine if nucleosome structure altered during this period, liver nuclei from sham-operated rats were compired with nuclei isolated at various times after partial hepatectomy. These nuclei were exposed to deoxyribonuclease I (EC 3.1.4.5), deoxyribonuclease II (EC 3.1.4.6) or micrococcal nuclease (EC 3.1.4.7) and the nucleosome-associated DNA length was ascertained. In no case was a difference in the DNA lengths associated with nucleosome structure observed. Differences were observed with regard to the histones and their relative association with nuclear material. When nuclei from normal rat livers were incubated in hypo-osmolar medium $9 \%$ of histone 1 and $4 \%$ of the other histones were released. These released histones, unlike those remaining bound to the nuclei, showed high $\left[{ }^{3} \mathrm{H}\right]$ adenosine and $\left[{ }^{3} \mathrm{H}\right]$ acetate uptakes in vivo. $\left[{ }^{32} \mathrm{P}\right] \mathrm{P}_{1}$ uptake was also much greater into released than bound histones 1 and 3, but was not different for histone 2A. At 3.5-4.5 h after partial hepatectomy, the release of histone 1 was trebled and that of histone 4 doubled. By $13.5 \mathrm{~h}$, when phosphorylation of the bound forms of histones $2 \mathrm{~A}$ and especially 1 was increased, no further changes in histone release in hypo-osmolar medium were found. The released histones from partially hepatectomized livers had indistinguishable $\left[{ }^{3} \mathrm{H}\right]$ adenosine uptakes from controls. The roles are discussed of phosphorylation and ADP-ribosylation in labilizing histone binding.
\end{abstract}

Changes in the post-synthetic modifications of histones and non-histones during the cell cycle are well known. Acetylation, phosphorylation and ADP-ribosylation may be expected to weaken interactions between proteins and DNA, but although morphological differences are apparent between interphase and metaphase cells, the patterns of DNA fragments released by nuclear attack on mitotic chromosomes and interphase nuclei are indistinguishable when examined by gel electrophoresis (Axel, 1976). On the other hand thermal stability, circular dichroism and dye-binding studies have shown correlations with the metabolic status in the cell cycle (for references, see Baserga, 1976).

In earlier experiments, we found (Fónagy et al., 1977) that when thymus nuclei were incubated in a slightly hypo-osmolar medium, phosphorylated histone and non-histone proteins were released into solution. We have been concerned here to investigate possible relationships between the chemical proper-

Abbreviation used: DNAase, deoxyribonuclease.

* Present address: Department of Biology, Case Western Reserve University, Cleveland, OHI 44106, U.S.A.

Vol. 174 ties of the released proteins and the amounts released at different times in the cell cycle in regenerating rat liver.

We have also attempted to see if DNA-protein interactions in nucleosomes obtained at the same time showed differences in morphology or nuclease digestibility from $\mathrm{G}_{0}$-phase through $\mathrm{S}$-phase, and to determine if the formation of poly(ADP-ribose) affects the quantity of DNA associated with liver nucleosomes.

\section{Materials and Methods \\ Animals}

Male rats of $70-90 \mathrm{~g}$ body wt. were kept from weaning in controlled lighting with a $12 \mathrm{~h}$ day. Partial hepatectomies were performed in the first hour of light; no further food was given to the animals from that time, but $10 \%(w / v)$ sucrose was available for drinking.

\section{Nuclei}

Nuclei were prepared either by the method of Chauveau et al. (1956) with $2.2 \mathrm{M}$-sucrose $/ 5 \mathrm{~mm}$ - 
$\mathrm{MgCl}_{2} / 10 \mathrm{~mm}$-Tris/HCl, pH7.4 $\left(\mathrm{Mg}^{2+}\right.$ nuclei) or by the bivalent ion-free method of Burgoyne et al. (1970).

\section{Nuclease digests}

Nuclei from regenerating, sham-operated or normal livers were suspended in the appropriate buffers (see below) at a concentration of $1 \mathrm{mg} / \mathrm{ml}$. For nuclease digestions, the DNA rendered acidsoluble at various time points was always monitored (Compton et al., 1976). Samples were taken at 0, 2, $5,10,15$ and $30 \mathrm{~min}$ and the nuclease was inactivated by the addition of EDTA ( $50 \mathrm{~mm}$ final concn.) or Tris buffer ( $50 \mathrm{~mm}$ final concn.), $\mathrm{pH} 10$, and placed on ice. Individual samples were exposed to DNAase-free ribonuclease, proteinase- $\mathrm{K}$ and sodium dodecyl sulphate, then extracted with phenol and chloroform/ octan-1-ol, and finally precipitated with ethanol/ sodium acetate (Compton et al., 1976; Bellard et al., 1976). Individual samples were taken up in $10 \mathrm{~mm}$ Tris (pH7.5)/1 mM-EDTA buffer, and the DNA concentrations determined optically by using the extinction coefficient of $22 / \mathrm{mg}$ of DNA per $\mathrm{ml}$ at $260 \mathrm{~nm}$; 1-3.5 $\mu \mathrm{g}$ of DNA was used for electrophoresis.

To determine the DNA repeat length above 150 base-pairs after using deoxyribonuclease or micrococcal nuclease, polyacrylamide gels containing $2 \%$ acrylamide and $0.5 \%$ agarose were run in an $11 \mathrm{~cm}$ long slab apparatus (Bellard et al., 1976). To investigate the DNA repeat pattern below 140 base-pairs, $98 \%$ formamide $/ 6 \%$ acrylamide gels were run as described elsewhere (Oudet et al., 1977). After electrophoresis, the gels were exposed to ethidium bromide $(0.5 \mu \mathrm{g} / \mathrm{ml})$ for $30 \mathrm{~min}$, destained in water for $5 \mathrm{~min}$, and detected with short-wavelength u.v. light and photographed through a red filter.

The conditions for nuclease digestions are as follows. Micrococcal nuclease (Worthington) was used at 1000 units $/ \mathrm{ml}$ at $20^{\circ} \mathrm{C}$ in a medium containing $1 \mathrm{mM}-\mathrm{CaCl}_{2}, 0.25 \mathrm{M}$-sucrose, $50 \mathrm{~mm}$-Tris/HCl, $\mathrm{pH} 7.5$,

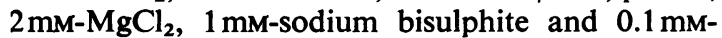
phenylmethanesulphonyl fluoride (Spadafora et al., 1976). DNAase I at 300 units $/ \mathrm{ml}$ was used at $37^{\circ} \mathrm{C}$ in a medium containing $0.25 \mathrm{M}$-sucrose, $50 \mathrm{~mm}$-Tris/ $\mathrm{HCl}, \mathrm{pH} 7.5,10 \mathrm{~mm}-\mathrm{MgCl}_{2}, 10 \mathrm{~mm}$-sodium bisulphite and $0.1 \mathrm{M}$-phenylmethanesulphonyl fluoride (Oudet et al., 1977). DNAase II at 1000 units $/ \mathrm{ml}$ was used at $37^{\circ} \mathrm{C}$ in a medium containing $10 \mathrm{~mm}-\mathrm{Tris} / \mathrm{HCl}$, 0.2 mm-EDTA, pH7.0, or pH5.0, 0.1 mm-phenylmethanesulphonyl fluoride and 1 mm-sodium bisulphite or the same buffer plus $2 \mathrm{mM}-\mathrm{MgCl}_{2}$ (Altenburger et al., 1976).

\section{Poly(ADP-ribosyl)ation}

The poly(ADP-ribosyl)ation reaction was performed by taking up nuclei in $0.25 \mathrm{M}$-sucrose, $50 \mathrm{~mm}$ Tris/HCl, $\mathrm{pH} 7.5,5 \mathrm{mM}^{-\mathrm{MgCl}_{2}}, 1 \mathrm{~mm}$-sodium bi- sulphite and $0.1 \mathrm{~mm}$-phenylmethanesulphonyl fluoride. The reaction was started by adding $5 \mathrm{~mm}-\mathrm{NAD}^{+}$ with $0.5 \mu \mathrm{Ci}$ of $\left[{ }^{3} \mathrm{H}\right]$ adenine-labelled $\mathrm{NAD}^{+}(5 \mu \mathrm{Ci} /$ mmol, from New England Nuclear, Boston, MA, U.S.A.) and incubating at $37^{\circ} \mathrm{C}$ with occasional shaking. At various times up to $180 \mathrm{~min}$, small samples were withdrawn and mixed with $2 \mathrm{ml}$ of icecold $20 \%$ trichloroacetic acid. After at least $30 \mathrm{~min}$ on ice, this material was filtered on a GC glass-fibre filter, the tube washed with $3 \times 5 \mathrm{ml}$ of ice-cold $20 \%$ trichloroacetic acid and the filter finally washed with ethanol. After drying, the filter was put into $5 \mathrm{ml}$ of Omnifluor/toluene and counted for radioactivity in a Packard scintillation spectrometer. Snake-venom phosphodiesterase analysis of incorporated radioactivity was performed (Shima et al., 1969; Miller, 1975) and confirmed that authentic poly(ADP-ribose) was formed in the presence and absence of nucleases.

\section{Nuclear incubation and histone isolation}

To examine histone modification and release, $0.5 \mathrm{ml}$ of nuclear suspensions $\left(\mathrm{Mg}^{2+}\right.$ nuclei, $2 \mathrm{mg}$ of $\mathrm{DNA} / \mathrm{ml}$ ) in $5 \mathrm{~mm}-\mathrm{MgCl}_{2}, 10 \mathrm{~mm}-\mathrm{Tris} / \mathrm{HCl}, \mathrm{pH} 7.4$, $2 \mathrm{~mm}-2$-mercaptoethanol were added to $0.5 \mathrm{ml}$ of medium [100 mM-Tris $/ \mathrm{HCl}(\mathrm{pH} 7.4) / 4 \mathrm{~mm}-\mathrm{ATP} / 1 \mathrm{~mm}-$ $\mathrm{MgCl}_{2}$ ]. The presence of ATP minimized protein phosphatase action during incubation. For determining the total histone content, $1 \mathrm{ml}$ of suspension was stopped at $0^{\circ} \mathrm{C}$ with $0.1 \mathrm{ml}$ of $60 \% \mathrm{HClO}_{4}$, and the histones were isolated as described below. Otherwise the suspensions were incubated for $20 \mathrm{~min}$ at $37^{\circ} \mathrm{C}$, brought to $0^{\circ} \mathrm{C}$ and centrifuged at $25000 \mathrm{~g}$ for $5 \mathrm{~min}$. Proteins present in the supernatant are 'released proteins'. The nuclear pellet remaining after centrifuging was extracted twice with $0.5 \mathrm{M}-\mathrm{HClO}_{4}$, and the 'bound' histone 1 precipitated by the addition of $100 \%(w / v)$ trichloroacetic acid to give a final concentration of $25 \%$. The 'bound' acid ethanol-soluble group of histones was then extracted in $4: 1(\mathrm{v} / \mathrm{v})$ ethanol/1.25 M-HCl (Johns, 1964). Large-scale preparations of liver histones were by methods previously described (Ord \& Stocken, 1975). Sometimes crude histone 1 was removed from the released proteins after precipitation at $0.5 \mathrm{M}-\mathrm{HClO}_{4}$, followed by precipitation of the supernatant at $25 \%$ trichloroacetic acid. Histones $2 \mathrm{~A}, 3$ and 4 could then be selectively removed in acid ethanol.

\section{Protein electrophoresis}

Polyacrylamide-gel electrophoresis at pH2.9 (Panyim \& Chalkley, 1969) or with sodium dodecyl sulphate at $\mathrm{pH} 7.0$ (Weber et al., 1973) was performed with cylindrical or slab gels. After staining with Coomassie Brilliant Blue the gels were scanned in a Vitatron TLD 100 scanner; where appropriate, $1 \mathrm{~mm}$ 
slices were taken for determination of their radioactivity.

\section{Quantitative estimation of histone released during incubation}

Electrophoretic analysis showed that although the 'total' histone 1 contained the non-histone chromosomal proteins HMG-1 and -2 (Smith \& Stocken, 1973; Shooter et al., 1974), these were absent from the 'bound' histone 1 obtained after removing the 'released' protein. The difference in amounts of protein (Lowry et al., 1951) between the total and bound histone 1 therefore represented the histone 1 released and all the non-histone proteins HMG-1 and -2. Polyacrylamide-gel electrophoresis of the released proteins at $\mathrm{pH} 2.9$ showed the presence of proteins HMG-1 and -2, histone 1 and traces of the other histones (see Fig. 2). The amount of proteins HMG-1 and -2 was determined in two ways: earlier experiments (Ord \& Stocken, 1975) had obtained quantitative recoveries of proteins HMG-1 and -2 after separation of the crude histone 1 on DEAE-cellulose at pH7.4; in normal rat liver proteins HMG-1 and -2 were then found to be $11 \pm 1 \%$ of the $0.5 \mathrm{M}-\mathrm{HClO}_{4}$-soluble proteins. Secondly, quantitative analysis of the gel slices gave the relative proportions of histone 1 to proteins HMG-1 and -2, assuming colour equivalence. Good agreement was obtained between the two methods. With the amount of histone 1 release determined, the release of the other histones was calculated from the scans of the released proteins by comparison with histone 1, again' assuming colour equivalence.

\section{DNA synthesis}

To check the timing of DNA synthesis and the extent of synchrony, $\left[{ }^{3} \mathrm{H}\right]$ thymidine was given $30 \mathrm{~min}$ before death from 20.5 to $24.5 \mathrm{~h}$ after partial hepatectomy. DNA was isolated and measured by the method of Burton (1956) and its radioactivity determined with respect to the plasma ${ }^{3} \mathrm{H}$ pool. Additionally, smears were made from portions of the liver at death: radioautography allowed the number of radioactive nuclei to be counted. In other experiments the rats were given $\left[{ }^{3} \mathrm{H}\right]$ thymidine $24 \mathrm{~h}$ after operation and killed between 28 and $31 \mathrm{~h}$. Portions of the livers were fixed and sectioned for radioautography. The peak rate of DNA synthesis in the rats was between 20.5 and $21 \mathrm{~h}$. Mitosis occurred between 29 and $30 \mathrm{~h}$; $30 \%$ parenchymal cells showed $\left[{ }^{3} \mathrm{H}\right]$ thymidine uptake and $16 \%$ of the mitoses were labelled. This balance between division and polyploidy after partial hepatectomy is as expected for rats of $80 \mathrm{~g}$ body wt.

\section{Isotope uptake}

$\left[{ }^{32} \mathrm{P}\right] \mathrm{P}_{\mathbf{1}}(1-3 \mathrm{Ci} / \mathrm{mmol}), \quad\left[\mathrm{G}-{ }^{3} \mathrm{H}\right]$ adenosine $(38 \mathrm{Ci} /$ mmol), $\left[6-{ }^{3} \mathrm{H}\right]$ thymidine $(23.3 \mathrm{Ci} / \mathrm{mmol})$ and $\left[{ }^{3} \mathrm{H}\right]-$ methyl acetate $(551 \mathrm{mCi} / \mathrm{mmol})$ were given to the rats intramuscularly $1-13 \mathrm{~h}$ before death. $\left[\gamma^{32} \mathrm{P}\right] \mathrm{ATP}$ was prepared by the method of Post \& Sen (1967). Unless otherwise stated, all isotopes were from The Radiochemical Centre, Amersham, Bucks., U.K. When comparisons were made between normal and partially hepatectomized rats, isotope uptakes were corrected for the specific radioactivities of the respective plasma or liver homogenate pools.

\section{Results}

Nuclease digestion of nuclei from regenerating rat livers

Nuclei from regenerating and sham-operated livers were prepared either by the method of Chauveau $e t$ al. (1956) or Burgoyne et al. (1970). These nuclei were exposed to DNAase I, DNAase II or micrococcal nuclease (Fig. $1 b$ ) and samples taken at various times, the DNA isolated and electrophoresed on agarose/ polyacrylamide gels. At early times during digestion by micrococcal nuclease and DNAase II in the presence of $\mathrm{MgCl}_{2}$, normal rat liver nuclei show a 200 base-pair repeat pattern (cf. Altenburger et al., 1976; Kornberg, 1977) (Fig. 1a). DNAase I gave a 10-base-pair repeat pattern up to 140 base-pairs (Oudet et al., 1977; Kornberg, 1977). In all cases, no differences in the pattern from sham-operated and regenerating liver nuclei could be detected.

In addition, a study has been made of $\left[{ }^{3} \mathrm{H}\right]$ thymidine uptake by regenerating rat livers in S-phase 15$60 \mathrm{~min}$ before death. Newly synthesized $\left[{ }^{3} \mathrm{H}\right] \mathrm{DNA}$ was analysed after nuclease digestion, on agarose/ polyacrylamide gels by fluorographic techniques (Seale, 1976, 1977) or by scintillation counting or by nucleosome isolation on isokinetic sucrose gradients (Kornberg, 1977). No evidence could be detected of non-coincidence between the distribution of ${ }^{3} \mathrm{H}$ radioactivity and either ethidium bromide binding to the DNA on the gels or u.v. absorption at $260 \mathrm{~nm}$.

Protein release from liver nuclei from control and partially hepatectomized rats during incubation in hypo-osmolar conditions

The polyacrylamide-gel-electrophoretic pattern (pH 2.9) of non-histone proteins released from liver nuclei during incubation (Fig. 2) was qualitatively different from that shown by thymus nuclei (Fónagy et al., 1977), but the amounts of histone were similar (Table 1) except for the smaller release of histone 3. As with thymus, the released histones were sharply distinguishable metabolically from the bound proteins by their greater uptake of isotope (Table 2 ).

In liver, bound histones 1 and 4 were insignificantly available to modification in control nuclei 


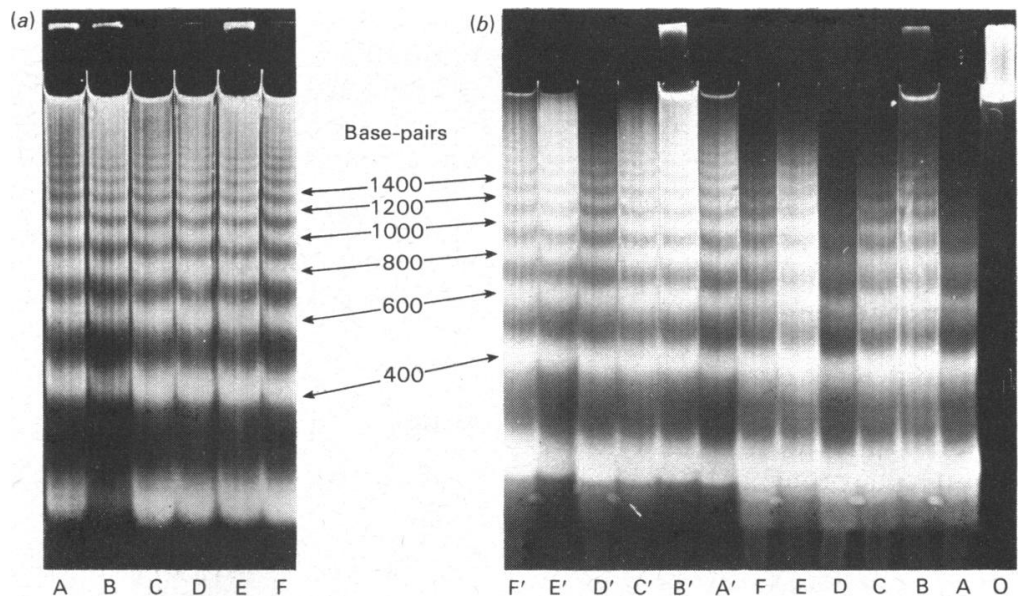

Fig. 1. Gel patterns of DNA from rat liver nuclei digested with DNAase II in the presence of $2 \mathrm{mM}-\mathrm{MgCl}_{2}($ a) or micrococcal nuclease (b)

Samples $A$ to $F$ represent $5 \mathrm{~min}$ of incubations while $A^{\prime}$ to $F^{\prime}$ represent $15 \mathrm{~min}$. Sample $A$ is the DNA from nuclei of sham-operated animals, while B-F represent samples from nuclei of livers from 14,21, 25, 28 and $48 \mathrm{~h}$ post-hepatectomy animals. The slot marked ' $O$ ' is the zero time nuclease sample of sample A, but was identical for B-F showing no digestion of DNA into smaller fragments. See the Materials and Methods section for other details.

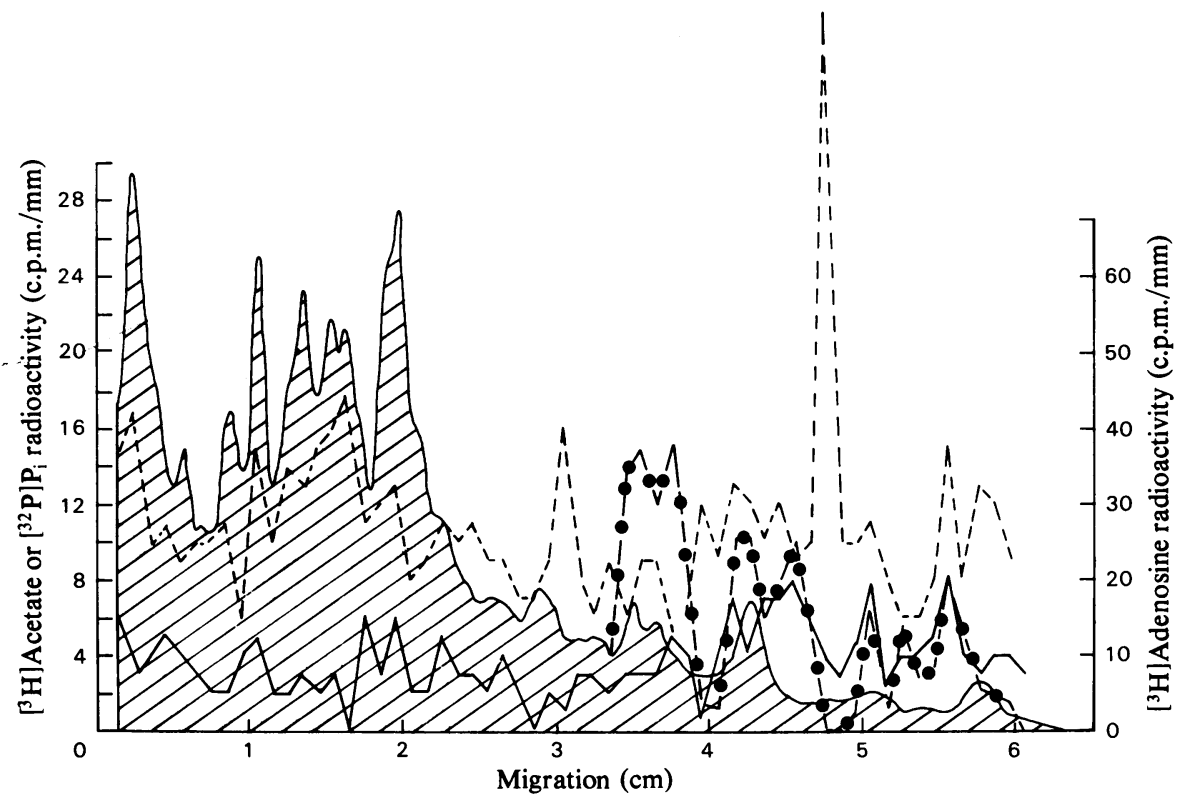

Fig. 2. Polyacrylamide-gel electrophoretic analysis ( $p H 2.9)$ of isotope uptake in vivo into proteins subsequently released after incubating rat liver nuclei

Protein $(25 \mu \mathrm{g})$ released from normal rat liver nuclei were applied to the gels. After staining and scanning of the gels, $1 \mathrm{~mm}$ slices were cut and their radioactivities determined by scintillation counting. Hatched areas show the densitometer scan.,$-{ }^{32} \mathrm{P}$ radioactivity after uptake for $1 \mathrm{~h}$ in vivo in normal rats. ----, $\left[{ }^{3} \mathrm{H}\right]$ acetate radioactivity after uptake for $1 \mathrm{~h}$ in vivo in rats partially hepatectomized $13.5 \mathrm{~h}$ before death. $-\bullet,\left[{ }^{3} \mathrm{H}\right]$ adenosine radioactivity after uptake for $13.5 \mathrm{~h}$ in vivo in normal rats. The non-histone chromosomal proteins HMG-1 and HMG-2 migrated $3.5-4 \mathrm{~cm}$, histone $14-4.5 \mathrm{~cm}$, histone $34.5-4.7 \mathrm{~cm}$, histone $2 \mathrm{~B} 4.7-4.9 \mathrm{~cm}$, histone $2 \mathrm{~A} 4.9-5.5 \mathrm{~cm}$ and histone $45.5-6.0 \mathrm{~cm}$. 
Table 1. Protein release from normal and partially hepatectomized rat liver nuclei

Rats were sham-operated or partially hepatectomized $3.5-4.5$ or $13-14 \mathrm{~h}$ before death. No detectable differences were seen between the two groups of partially hepatectomized rats and the results were therefore taken together. Nuclei were incubated at $37^{\circ} \mathrm{C}$ for $20 \mathrm{~min}$ in a hypo-osmolar solution under conditions described in the text. Released proteins were those present in the supernatant after the incubated nuclei had been brought to $0^{\circ} \mathrm{C}$ and centrifuged for $5 \mathrm{~min}$ at $25000 \mathrm{~g}$. Bound histone 1 was that present in the nuclear pellet after the removal of the released proteins. Total histone 1 and proteins HMG-1 and HMG-2 were those proteins present in the nuclear suspensions which were stopped by $\mathrm{HClO}_{4}$ before incubation. The amounts of non-histone chromosomal proteins (HMG-1 and HMG-2) were reported earlier (Ord \& Stocken, 1975), and confirmed in these experiments. Released histone 1, which was ADPribosylated, could then be calculated (see the text) as could the amounts of the other histones released during the incubation. Released proteins are expressed as $\mu \mathrm{g}$ of protein $/ \mathrm{mg}$ of DNA or as $\%$ of total histones $1,3,2 \mathrm{~B}, 2 \mathrm{~A}$ or $4 \pm$ S.E. (number of determinations given in parentheses).

Released protein

Total histone 1, protein HMG-1 and HMG-2

Bound histone 1

Protein HMG-1 and HMG-2

Released histone 1 (1a)

Released histone 3, 2B, 2A

Released histone 4

Control liver nuclei
$961 \pm 190(11)$
$180 \pm 36.9(9)$
$139 \pm 20.9(9)$
$25 \pm 5.5(11)$
$16(9 \%)(9)$
$3.9 \pm 1.5 \%(8)$
$3.4 \pm 2.0 \%(8)$

Partially hepatectomized liver nuclei

$1166 \pm 87$ (6)

$180 \pm 50.6(6)$

$113 \pm 18.9(6)$

$20 \pm 10.2(6)$

$47(29 \%)(6)$

$4.7 \pm 0.8 \%(4)$

$7.4 \pm 1.9 \%(4)$

Table 2. Isotope uptake into histones from control and partially hepatectomized rat liver nuclei

The preparation of nuclei, incubation conditions and isolation of histones are described in the text. $\left[{ }^{32} \mathrm{P}\right] \mathrm{P}_{1}$ and $\left[{ }^{3} \mathrm{H}\right]-$ acetate uptakes in vivo $(a, c)$ are given as c.p.m./nmol. Transfer of $\left[\gamma_{-}{ }^{32} \mathrm{P}\right]$ ATP is given as mmol of $\gamma-\mathrm{P}$ transferred $/ \mathrm{mol}$ of protein \pm S.E. To determine the radioactivity of the released proteins, ${ }^{32}[\mathbf{P}] \mathbf{P}_{1}$ and ${ }^{3} \mathrm{H}$ adenosine uptakes were obtained after isolating the histones from the soluble proteins by classical methods. For $\left[{ }^{3} \mathrm{H}\right]$ acetate uptake and for $\left[\gamma_{-}{ }^{32} \mathrm{P}\right] \mathrm{ATP}$ transfer the results were obtained by radioactivity counting of the gel. Neither $\left[\gamma_{-}{ }^{32} \mathrm{P}\right] \mathrm{ATP}$ transfer nor $\left[{ }^{3} \mathrm{H}\right] \mathrm{adenosine}$ uptakes in vivo differed between control livers and those after partial hepatectomy; the latter results, which are expressed as the ratio of ${ }^{3} \mathrm{H}$ radioactivity of the released: bound histones, are the means of two experiments which did not differ by more than $5 \%$.

(a)

$\left[{ }^{32} \mathrm{P}\right] \mathrm{P}_{1}$ uptake in vivo (c.p.m. $\left./ \mathrm{nmol}\right)$

\begin{tabular}{llcc}
\cline { 3 - 4 } Histone & \multicolumn{3}{c}{ Released histones } \\
\cline { 2 - 4 } & Control & $\begin{array}{c}6 \mathrm{~h} \text { post } \\
\text { hepatectomy }\end{array}$ & $\begin{array}{c}13.5 \mathrm{~h} \text { post } \\
\text { hepatectomy }\end{array}$ \\
H1 & $29.7 \pm 5.2(3)$ & 35.0 & 32.7 \\
H3 & 176 & 116 & - \\
H2A & $25.6,14.1$ & 33.3 & -
\end{tabular}

(b)

$\begin{array}{cc}\text { Histone } & \begin{array}{c}\text { Released } \\ \text { histones }(4)\end{array} \\ \text { H1 } & 26.8 \pm 8.0 \\ \text { H3 } & 55.1 \pm 9.4 \\ \text { H2B } & 32.0 \pm 16.0 \\ \text { H2A } & 24.7 \pm 8.3 \\ \text { H4 } & 34.3 \pm 3.7\end{array}$

(d)
[ $\left.\gamma_{-}{ }^{32} \mathrm{P}\right] \mathrm{ATP}$ uptake in vitro (c.p.m./nmol)

\begin{tabular}{ccc}
\multicolumn{3}{c}{ Bound histones } \\
$\begin{array}{c}\text { Control } \\
(4)\end{array}$ & $\begin{array}{c}3.5-4 \mathrm{~h} \text { post } \\
\text { hepatectomy } \\
(3)\end{array}$ & $\begin{array}{c}13.5 \mathrm{~h} \text { post } \\
\text { hepatectomy } \\
(3)\end{array}$ \\
$2.5 \pm 1.4$ & $6.9 \pm 1.9$ & $13.6 \pm 3.6$ \\
$10.8 \pm 1.3$ & 19.4 & $12.6 \pm 5.7$ \\
$18.5 \pm 3.6$ & $20.9,0.6$ & $30.8 \pm 25.6$
\end{tabular}

(c) $\left[{ }^{3} \mathrm{H}\right]$ Acetate uptake in vivo (c.p.m./nmol)

$\begin{array}{cc}\begin{array}{c}\text { Released } \\ \text { histones (1) }\end{array} & \begin{array}{c}\text { Bound } \\ \text { histones (1) }\end{array} \\ - & - \\ \overline{550} & 6.0 \\ 1081 & \overline{-} \\ 726 & 0\end{array}$

[ ${ }^{3} \mathrm{H}$ ]Adenosine uptake in vivo (ratio of ${ }^{3} \mathrm{H}$ radioactivity in released and bound histones)

$\begin{array}{crrcc}\text { Labelling time (h) } & \ldots & 1(2) & 4.5(2) & 13.5(2) \\ \text { H1 } & & 4.4 & 12.0 & 17.9 \\ \text { H3 } & & 13.9 & 26.9 & 26.6 \\ \text { H2A } & & 2.1 & 20.5 & 4.5\end{array}$


(Table 2, $a-d$ ); bound histones 3 and $2 \mathrm{~A}$ showed [ $\left.{ }^{32} \mathbf{P}\right] \mathbf{P}_{1}$ incorporation (Table $2, a-b$ ), but little $\left[{ }^{3} \mathrm{H}\right]-$ adenosine uptake (Table $2, d$ ). The extent of ${ }^{32} \mathrm{P}$ uptake in vivo into histone $2 \mathrm{~A}$ was not different between the released and bound proteins (Table 2,a). That this difference was observed with phosphorylation in vitro is possibly due to the release of histones under the conditions of incubation and their consequential availability to phosphokinase and phosphatases (Fónagy et al., 1977). Adenosine uptake into the released proteins (Fig. 2 and Table $2 d$ ) is consistent with our earlier studies on adenine uptake and ADPribosylation (Ord \& Stocken, 1977). There the histones had not been separated into released and bound fractions and ADP-ribosylation of histone 2A was then only seen after incubation with NAD, and was not detected on histone 4.

Histone 1 and the non-histone proteins HMG-1 and -2 were isolated from the released proteins by classical methods. U.v. analysis then showed that these proteins contained about $1 \mathrm{~mol}$ of adenine $/ \mathrm{mol}$ of protein. Protein HMG-1 dominated the electrophoretic pattern at $\mathrm{pH} 2.9$; the histone 1 present in the released proteins also migrated significantly more slowly than bound histone 1 (Fig. 3). All the proteins HMG-1 and HMG-2 were released during incubation, and chromatographic separation of bound histone 1 on DEAE-cellulose and Bio-Rex 70 (Smith \& Stocken, 1973) confirmed that all the proteins HMG-1 and HMG-2 and all the ADP-ribosylated histone 1 had been released into the hypo-osmolar incubation medium. The ethanol/HCl-soluble histones $2 \mathrm{~A}, 3$ and 4 could also be recovered from the released proteins.

The results indicate that the released proteins carry more than one modification. We suggest that simple phosphorylation provides seryl phosphate groups to act as acceptors for ADP-ribose. If ADP-ribosylation occurs, the proteins dissociate under hypo-osmolar conditions, although from quantitative recoveries of histone 1 (Table 1) and histones 2A, 3 and 4 (not shown) from all the nuclei examined in these experiments, and from the constancy of the nuclear digest patterns, complete histone dissociation does not occur in vivo.

Partial hepatectomy tripled the release of histone 1 and doubled that of histone 4 (Table 1). This was seen at $3.5 \mathrm{~h}$, the earliest time examined (bound histone 1 now $112 \pm 19.2 \mu \mathrm{g} / \mathrm{mg}$ of DNA) and was not significantly different $13-14 \mathrm{~h}$ after operation (Table 1), when the phosphate contents of histones 1 and $2 \mathrm{~A}$ are greatly increased (Thrower et al., 1975). Partial hepatectomy increased ${ }^{32} \mathrm{P} \mathrm{P}_{1}$ uptakes in vivo into bound histones 1 and $2 \mathrm{~A}$ (Table $2 a$ ), especially at $13.5 \mathrm{~h}$, consistent with the expected prereplicative increase in ${ }^{32} \mathrm{P}$ specific radioactivity of these proteins (Thrower et al., 1975). [ $\left.{ }^{3} \mathrm{H}\right]$ Adenosine uptakes were unchanged, as were the adenine contents of the non-

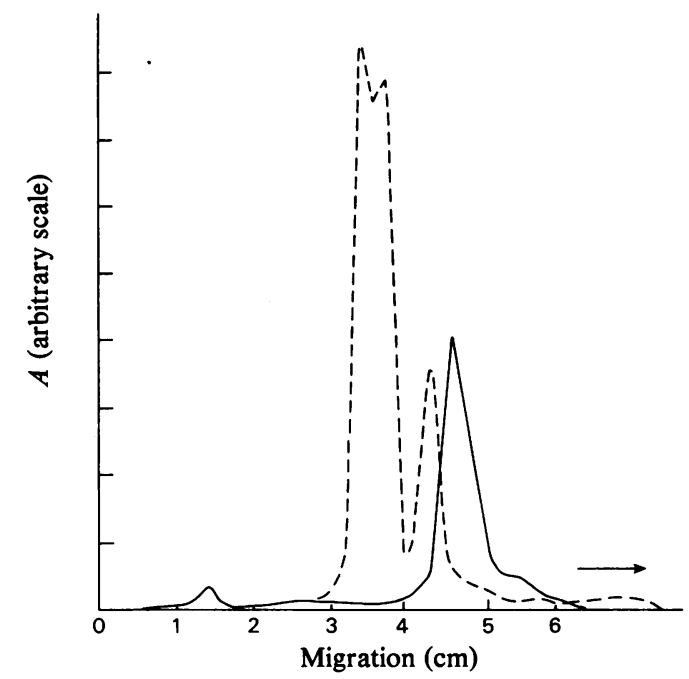

Fig. 3. Polyacrylamide-gel electrophoresis ( $\mathrm{HH2.9)}$ of $0.5 \mathrm{M}-\mathrm{HClO}_{4}$-soluble material from released and bound proteins of liver nuclei incubated in hypo-osmolar conditions

The supernatant released during nuclear incubation was made $0.5 \mathrm{M}$ in $\mathrm{HClO}_{4}$. The soluble material was brought to $25 \%$ in trichloroacetic acid; $10 \mu \mathrm{g}$ of protein was applied to the gel. The nuclear pellet from which the soluble proteins had been released during incubation was similarly treated; $2 \mu \mathrm{g}$ of protein was applied to the gel. ----, Acid (0.5 M$\mathrm{HClO}_{4}$ )-soluble proteins released during nuclear incubation.,$- 0.5 \mathrm{M}-\mathrm{HClO}_{4}$-soluble protein remaining bound to the nuclei. Protein HMG-1 ran at about $3.5 \mathrm{~cm}, \mathrm{HMG}-2$ at about $3.8 \mathrm{~cm}$; histone 1 ran between 4.2 and $4.5 \mathrm{~cm}$.

histone chromosomal proteins HMG-1 and HMG-2 and histone 1 released into the incubation medium. $\left[{ }^{3} \mathrm{H}\right]$ Acetate uptake by the released protein was increased $13.5 \mathrm{~h}$ after partial hepatectomy (Fig. 2); the uptakes into histones $1,2 \mathrm{~A}$ and 4 at this time are probably associated with the onset of histone biosynthesis and $N$-terminal acetylation.

Under our experimental conditions phosphorylation by the nuclear kinase(s) in vitro was indistinguishable 4 and $13.5 \mathrm{~h}$ after partial hepatectomy from that in normal liver nuclei. This suggests that in $G_{1}$-phase the increased phosphorylation of histones in vivo may be effected by a kinase that is not retained by the nuclear preparation, in contrast with the increased activity of a nuclear kinase phosphorylating histone 1 , detectable in these nuclei in S-phase (Siebert et al., 1971).

\section{ADP-ribosylation and nuclease digestion patterns}

Using nuclei isolated from normal rats, the effects of poly(ADP-ribose) formation in vitro on nucleosome structure was investigated. The incorporation 
of $\left[{ }^{3} \mathrm{H}\right]$ adenine from NAD into nuclei was followed as trichloroacetic acid precipitable material (Fig. 4). In all cases, exposure to nuclease resulted in a $10-41 \%$ increase in the rate of ADP-ribosylation. Analysis of the snake-venom phosphodiesterase hydrolysate of this trichloroacetic acid precipitable material indicated that the average chain length of newly formed poly(ADP-ribose) was 3.1-3.4, and that about $0.37 \mathrm{~mol}$ of ADP-ribose was incorporated $/ \mathrm{h}$ per $\mathrm{mol}$ of histone.

With all conditions used, and variations of bivalent cation between 0.5 and $10 \mathrm{~mm}$ and of NAD from 0.5 to $5 \mathrm{~mm}$, no differences in the DNAase I, DNAase II and micrococcal nuclease digestion patterns could be detected between nuclei from controls and those showing poly(ADP-ribose) formation. In experiments involving DNAase II with $\mathrm{MgCl}_{2}$ present in the poly(ADP-ribosyl)ation reaction, the 200-base-pair and not the 100-base-pair repeat pattern was observed (cf. Fig. 1b). A variety of methods was used to remove the $\mathrm{Mg}^{2+}$ from nuclei in unsuccessful attempts to detect the 100-base-pair repeat pattern; these included addition of $50 \mathrm{~mm}$-EDTA, dialysis against $10 \mathrm{~mm}-\mathrm{Tris} / \mathrm{HCl}, \mathrm{pH} 8$, and dialysis against $50 \mathrm{~mm}-$ EDTA, pH 7.5. The ADP-ribosylation reaction was therefore conducted for $1 \mathrm{~h}$ at $37^{\circ} \mathrm{C}$ in the absence of

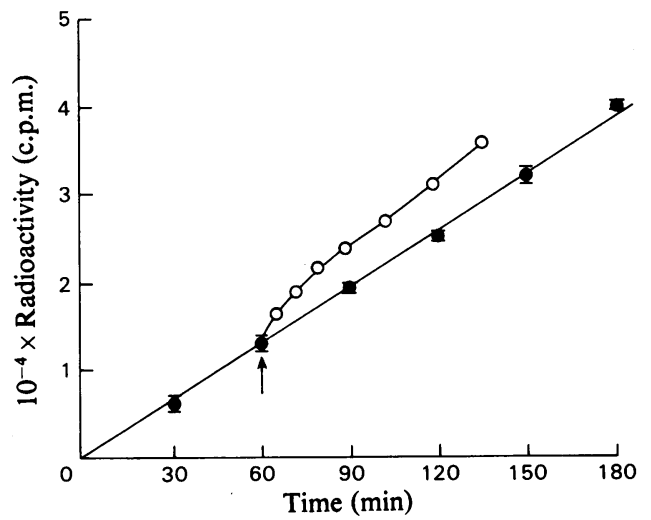

Fig. 4. Formation of poly(ADP-ribose) in the presence or absence of micrococcal nuclease as determined by the trichloroacetic acid-precipitability of radioactivity originating in $\left[{ }^{3} H\right] N A D$

Isolated rat liver nuclei were incubated for various times after which they were brought to $0^{\circ} \mathrm{C}$ and made $20 \%$ (final) trichloroacetic acid. After $60 \mathrm{~min}$ of incubation, micrococcal nuclease was added (arrow) to a portion of incubating nuclei and after various time periods these samples were precipitated with trichloroacetic acid on ice. The trichloroacetic acidprecipitable material was trapped on glass-fibre filters, washed with ethanol and estimated. $\bigcirc$, Micrococcal nuclease; $\bullet$, control.
$\mathrm{MgCl}_{2}$ using nuclei prepared by the method of Burgoyne et al. (1970), followed by exposure to DNAase II also in the absence of $\mathrm{MgCl}_{2}$. The trichloroacetic acid-precipitable radioactivity was 100 to 450-fold less than the ADP-ribosylation in the presence of $\mathrm{Mg}^{2+}$, but showed an increase in radioactivity with time; nuclease treatment did not stimulate this rate. Furthermore, the snake venom phosphodiesterase pattern indicated minimal, if any, formation of poly(ADP-ribose), but perhaps a small amount of the monomer.

\section{Discussion}

Nuclease digestion patterns have been used to characterize the structural complexity of nucleosomes. The amount of DNA associated with nucleosomes seems to vary as a function of the transcriptive (Thomas \& Thompson, 1977) or replicative (Seale, $1976,1977)$ activity of a group of cells or tissue. Two variables that affect cell activity and/or nucleosome structure have been investigated here: effects of regeneration and ADP-ribosylation in vitro. Regeneration involves relatively substantial modifications of nuclear proteins, including phosphorylation, acetylation and ADP-ribosylation, as well as amounts of non-histone proteins. No differences in the DNAase I, DNAase II or micrococcal nuclease patterns could be detected, however. Three interpretations are possible: first, these major and relatively massive chemical modifications and alterations in tissue activities do not produce modifications in nucleosome structure; secondly, the level or type of modification is below the resolution of the techniques used or, thirdly, the conditions under which the nuclease experiments are performed preclude detection of any changes.

Modification of nucleosome morphology was not apparent under our conditions. The technology used is easily capable of detecting a $10 \%$ change in the amount of DNA associated with the nucleosomes. Such a $10 \%$ change would result in a 20 -base-pair shift in the repeat frequency of nucleosomes. The agarose/polyacrylamide gel system can resolve 10base-pair differences. If only $10-20 \%$ of the nuclei are involved in the ADP-ribosylation or regeneration response and these nuclei exhibited a $10 \%$ shift in the amount of DNA associated with the nucleosome, we would expect a 'smearing' of the monomer or multimer DNA bands. This was not observed either in visually inspected gels, optically scanned gels, or in gels subjected to fluorographic analysis. We must therefore conclude that although the nuclease and gel technology are capable of detecting relatively small differences in nucleosome structure, under the conditions used here no such differences could be detected. 
The identity of the nuclease digest patterns contrasts with the increased dissociation of some of the nuclear proteins in the hypo-osmolar incubation conditions. Histones released from normal liver nuclei were highly modified; the extent of their release $(4 \%$ of core histones and $9 \%$ histone 1) is consistent with current estimates for the proportion of transcriptionally active DNA. Their greater release (5-7 and $29 \%$ respectively) by $3.5 \mathrm{~h}$ after partial hepatectomy would then correlate with well-established increases in transcriptional activity early in $\mathbf{G}_{\mathbf{1}}$-phase.

Simple phosphorylation, like acetylation (Davie \& Candido, 1977), may not be sufficient to labilize histone-DNA interactions in the tests used here. The results suggest that for increased transcriptional or replicative activity multiple and possibly co-operative modifications of the same protein are required.

There is a temporal correlation between the first peak of cyclic AMP production in regenerating liver (Thrower et al., 1975), the increased phosphorylation of histone 1 , and its increased release from incubated nuclei $3.5 \mathrm{~h}$ after partial hepatectomy. As the specific radioactivity of $\left[{ }^{3} \mathrm{H}\right]$ adenosine in the released histone 1 is unchanged, more ADP-ribosylation of histone 1 must have occurred. Amounts of poly(ADP-ribose) polymerase are not thought to increase early in $G_{1}$-phase (Hilz \& Stone, 1976). The increased ADP-ribosylation of histone 1 may therefore be consequential upon the increase in serine phosphorylation, but by $13.5 \mathrm{~h}$, when phosphorylation of histone 1 is greatly increased, no further release of the protein was detectable. This suggests either that the activity of the poly(ADP-ribose) polymerase became limiting, or that other factors, which may include the presence of non-histone proteins, are additionally involved.

Partial hepatectomy causes a profound change in the activity in the remaining liver cells as compared with sham-operated controls. As shown here, this change in activity is accompanied by an increase in the release of proteins from isolated nuclei without affecting the repeat pattern of the DNA associated with histones in nucleosomes. These observations might indicate that the histone octomer shifts away from and then reassociated with DNA, as determined by the chemical modifications of the nuclear proteins. We would suggest that the release of various proteins (modified histones for example) may be the result of this activity. If nucleosomes are mainly but not exclusively associated with transcriptively inactive DNA sequences, the identity of the nucleosomedigestion patterns seen here would indicate that DNA-histone interactions in liver cell chromatin were quantitatively indistinguishable regardless of the state of activity of this tissue. Further, the shifts in transcriptive and replicative activity probably require the modification of certain nuclear proteins associated with previously active or newly active sequences; such modifications have no effect on the quantity of DNA associated with individual stable nucleosomes.

A.I.C. was supported by a Josiah Macy, Jr., Faculty Scholar Award and he gratefully acknowledges the generous support of the C.N.R.S. and Professor Pierre Chambon, in whose laboratory some of the work was conducted. He also thanks Dr. Corrado Spadafora for his help and advice. L.A.S. and M.G.O. are grateful to Mrs. J. Waldron and Mr. R. Brightman for their skilled assistance and to the Wellcome Trust for financial assistance towards the cost of equipment.

\section{References}

Altenburger, W., Horz, W. \& Zachau, H. G. (1976) Nature (London) 264, 517-522

Axel, R. (1976) Prog. Nucleic Acid Res. Mol. Biol. 19, 355-371

Baserga, R. (1976) Multiplication and Division in Mammalian Cells: The Biochemistry of Diseases (Farber, E. \& Pitot, H. C., eds.), vol. 6, Marcel Dekker, New York and Basle

Bellard, M., Oudet, P., Germond, J. E. \& Chambon, P. (1976) in Dahlem Workshop on Organization and Expression of Chromosomes, Life Sciences Research Report No. 4: Organization and Expression of Chromosomes (Allfrey, V. G., Bautz, E. K. F., McCarthy, B. J., Schimke, R. T. \& Tissières, A., eds.), Köhn and Schneider, Greenwich, CN

Burgoyne, L. A., Waqur, M. A. \& Atkinson, M. R. (1970) Biochem. Biophys. Res. Commun. 39, 254-259

Burton, K. (1956) Biochem. J. 62, 315-323

Chauveau, J., Moulé, Y. \& Rouiller, Ch. (1956) Exp. Cell Res. 11, 317-321

Compton, J. L., Bellard, M. \& Chambon, P. (1976) Proc. Natl. Acad. Sci. U.S.A. 73, 4382-4386

Davie, J. R. \& Candido, E. P. M. (1977) J. Biol. Chem. 252, 5962-5966

Fónagy, A., Ord, M. G. \& Stocken, L. A. (1977) Biochem. J. 162, 171-181

Hilz, H. \& Stone, P. (1976) Rev. Physiol. Biochem. Pharmacol. 76, 1-58

Johns, E. W. (1964) Biochem. J. 92, 55-59

Kornberg, R. (1977) Annu. Rev. Biochem. 46, 931-954

Lowry, O. H., Rosebrough, N. J., Farr, A. L. \& Randall, R. J. (1951) J. Biol. Chem. 193, 265-275

Miller, E. G. (1975) Biochem. Biophys. Res. Commun. 66, 281-286

Ord, M. G. \& Stocken, L. A. (1975) Proc. FEBS Meet. 9th 34, 113-125

Ord, M. G. \& Stocken, L. A. (1977) Biochem. J. 161, 583-592

Oudet, P., Bellard, M., Spadafora, C. \& Chambon, P. (1977) Cold Spring Harbor Symp. Quant. Biol. in the press

Panyim, S. \& Chalkley, R. (1969) Biochemistry 8, 39723979

Post, R. L. \& Sen, A. K. (1967) Methods Enzymol. 10, 773-775

Seale, R. L. (1976) Cell 9, 423-429

Seale, R. L. (1977) Cold Spring Harbor Symp. Quant. Biol. in the press 
Shima, T., Hasegawa, S., Fujimura, S., Matsabara, H. \& Sugimura, T. (1969) J. Biol. Chem. 244, 6632-6635

Shooter, K. V., Goodwin, G. H. \& Johns, E. W. (1974) Eur. J. Biochem. 47, 263-270

Siebert, G., Ord, M. G. \& Stocken, L. A. (1971) Biochem. J. 122, 721-725

Smith, J. A. \& Stocken, L. A. (1973) Biochem. J. 131, 859-861
Spadafora, C., Bellard, M., Compton, J. L. \& Chambon, P. (1976) FEBS Lett. 69, 281-285

Thomas, J. O. \& Thompson, R. J. (1977) Cold Spring Harbor Symp. Quant. Biol. in the press

Thrower, S., Ord, M. G. \& Stocken, L. A. (1975) SubCell. Biochem. 4, 147-156

Weber, K., Pringle, J. R. \& Osborn, M. (1973) Methods Enzymol. 26, 3-27 